\title{
Prevalence of Natural Enemies of Red Mite, Tetranychus bioculatus (Wood-Mason) in Marigold Gardens
}

\author{
M.A. TALEB ${ }^{1 *}$ AND M.A. SARDAR ${ }^{2}$ \\ ${ }^{1}$ School of Agriculture and Rural Development, Bangladesh Open University, Gazipur, Bangladesh \\ ${ }^{2}$ Department of Entomology, Bangladesh Agricultural University, Mymensingh, Bangladesh
}

\begin{abstract}
An investigation was carried out on the natural enemies of red mite, Tetranychus bioculatus in the marigold gardens. Insects and spiders both were found to occur as the predators of red mite. Two species of lady bird beetle viz. Stethorus punctillum, Micraspis discolor and two species of spiders e.g. lynx spider (Oxyopes sp.), long mouth spider (Tetragatha sp.) were encountered. Micraspis discolor and spiders were more than S. punctillum. The abundance of predator population was positively correlated with the abundance of their mite prey.
\end{abstract}

Key words: Natural enemies, red mite, marigold.

\section{INTRODUCTION}

The use of pesticides is the usual practice for red mite control on different crops. Pesticidal control of mite is not only expensive, but also indiscriminate and frequent use of pesticides causing several hazards (Goodland et al. 1985; Devi et al. 1986; Fishwick, 1988; Bhaduri et al. 1989). The pesticide application alters pest and predator/parasitoid ratios in the agroecosystem inflicting more harm rather than good.

The flower growers in developed countries use minimum amount of pesticide or avoid the application of pesticides. In recent years, mite control practice has been revolutionized by the application of predators in those countries. Zhang, et al.(2001) and Gorski and Eajfer (2003) provided some information on biological control of red mite by different predators in various horticultural plants and field crops.

The population growth of many mite species is efficiently controlled by their natural enemies (Nucifora and Vacante, 1985). Many predators like Typhlodromus pyri reduce the population growth of mites in natural condition (Kneifl and Kaourkova, 1991). Different species of insect predators also play significant role on the population suppression of mites. The interacting components between natural enemies and prey should clearly be understood to enhance or augment the effect of natural enemies in a prey population (Rabb, 1974). The interacting components include functional response occurring at individual level of both predator and prey and numerical response occurring at population level of both predator and prey (Holling, 1959).

* Corresponding author: Associate Professor, SARD, BOU; Tel: 88-02-9291101-4/327

(C) 2006 School of Agriculture and Rural Development, Bangladesh Open University, All rights reserved. 
Several species of coccinellid beetles are known to be predaceous on different species of mites, most common predaceous species being Stethorus punctillum. They have been successfully employed in the biological control of many injurious mites (Shojai et al. 1996), and is widely distributed in European countries as a most common mite pest feeding species. The other coccinellid beetle, Micraspis discolor is distributed in many countries of Asia namely, Bangladesh, India, Formosa (Taiwan) and Malaysia (Islam and Nasiruddin, 1978). M. discolor is not only predaceous, but also phytophagous (Omkar, 2006). They are predaceous on various important insect pests such as aphids, brown plant hoppers, thrips, cocccids, jassids, corn borers, lepidopteran insects, scale insects, mealy bugs, white backed plant hoppers, white flies and other soft bodied insects (Sumalde et al. 1993; Mani, 1995; Palaniswami et al. 1995). These predatory beetles can be used as viable agents for the biological control of the mites. Until recently, biological control was considered harmless and any available and promising species were tried. The main theme of this study is to investigate the natural enemies of red mite with special reference to predators and their influence as biocontrol agents in the garden ecosystem.

\section{MATERIALS AND METHODS}

The natural enemies in association with red mite, Tetranychus bioculatus on marigold plants were investigated in the Bangladesh Agricultural University (BAU) campus, Mymensingh during November, 2004 to March, 2005. The investigation was made on three different locations like in Veterinary Faculty, Botanical Garden and Horticulture Farm of BAU. Sampling was done from randomly selected five infested marigold plants in each garden at 7 days interval. Five replicates were used for each predator considering one plant as a replicate. The species of spiders and lady bird beetles such as Stethorus punctillum and Micraspis discolor were counted carefully using magnifying glass by weekly sampling and their numbers were subject to statistical analysis. Keys described by Okuma et al. (1993) and Sathe and Bhosale (2001) were used to identify the spiders and ladybird beetles, respectively. The gardens were kept free from pesticides use throughout the study period.

An attempt was also made to look into the parasitization of red mite using their larvae, nymphs and adults in the laboratory.

\section{RESULTS}

\section{Predators of red mite in marigold}

Different species of predators of red mite were observed in the gardens. Among these, two species of lady bird beetle namely Stethorus punctillum, Micraspis discolor and two species of spiders viz. lynx spider (Oxyopes sp.), long mouth spider (Tetragatha sp.) were found in the experimental gardens (Plate 1). The details on these predators are presented in Tables 1, 2 and 3. The predators occurred in all the three gardens during the vegetative to flowering stages of marigold plants.
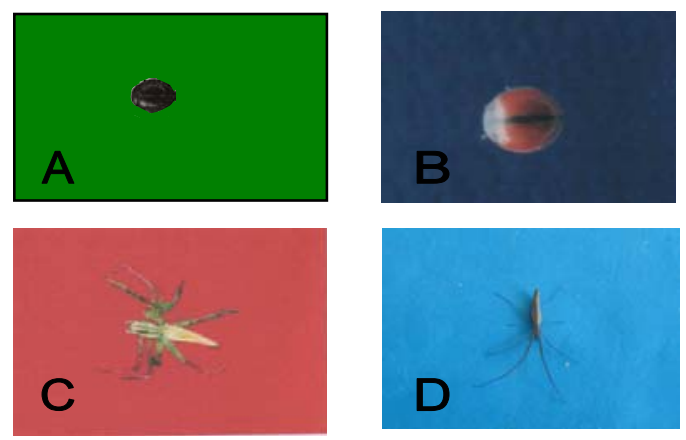

Plate 1. Predators A) Stethorus punctillum, B) Micraspis discolor, C) Oxyopes sp. and D) Tetragatha sp. 
Table 1. Number of predators occurred at vegetative and reproductive stages of red mite infesting marigold plants in Garden I (2004-2005)

\begin{tabular}{|c|c|c|c|c|c|c|c|}
\hline \multirow{4}{*}{$\begin{array}{l}\text { Plant } \\
\text { stages }\end{array}$} & \multirow{4}{*}{ Sampling week } & \multicolumn{6}{|c|}{ Adult predator (no.)/plant } \\
\hline & & \multicolumn{6}{|c|}{ Garden I } \\
\hline & & \multicolumn{2}{|c|}{ Stethorus punctillum } & \multicolumn{2}{|c|}{ Micraspis discolor } & \multicolumn{2}{|c|}{ Spiders } \\
\hline & & Range & $\bar{X} \pm \mathrm{SE}$ & Range & $\bar{X} \pm \mathrm{SE}$ & Range & $\bar{X} \pm \mathrm{SE}$ \\
\hline \multirow{11}{*}{ 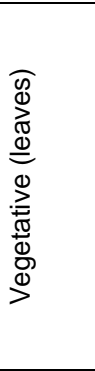 } & 2004 & & & & & & \\
\hline & November 1 & - & - & - & - & - & - \\
\hline & 2 & - & - & - & - & - & - \\
\hline & 3 & - & - & $0-1$ & $0.4 \pm 0.55$ & - & - \\
\hline & 4 & - & - & $0-1$ & $0.4 \pm 0.55$ & $0-1$ & $0.4 \pm 0.55$ \\
\hline & December 1 & $0-1$ & $0.2 \pm 0.45$ & $1-2$ & $1.0 \pm 1.0$ & $0-1$ & $0.40 \pm 0.55$ \\
\hline & 2 & $0-1$ & $0.2 \pm 0.45$ & $1-2$ & $1.4 \pm 0.55$ & $1-2$ & $1.2 \pm 0.84$ \\
\hline & 3 & $0-1$ & $0.4 \pm 0.55$ & $1-3$ & $1.6 \pm 1.14$ & $1-3$ & $1.6 \pm 1.14$ \\
\hline & 4 & $0-1$ & $0.4 \pm 0.55$ & $1-3$ & $2.4 \pm 0.89$ & $1-4$ & $2.0 \pm 1.41$ \\
\hline & 2005 & & & & & & \\
\hline & January 1 & $0-2$ & $1.4 \pm 0.89$ & $2-4$ & $3.0 \pm 1.0$ & $2-6$ & $3.4 \pm 1.67$ \\
\hline \multirow{9}{*}{ 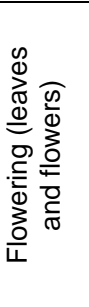 } & 2 & $0-3$ & $1.8 \pm 1.30$ & $2-5$ & $3.4 \pm 1.34$ & $1-6$ & $3.6 \pm 2.07$ \\
\hline & 3 & $0-3$ & $2.0 \pm 1.22$ & $2-6$ & $4.2 \pm 1.48$ & $2-9$ & $4.0 \pm 2.91$ \\
\hline & 4 & $1-4$ & $2.4 \pm 1.14$ & $2-7$ & $4.6 \pm 2.07$ & $2-8$ & $4.2 \pm 2.28$ \\
\hline & February 1 & $0-3$ & $2.0 \pm 1.41$ & $3-6$ & $4.0 \pm 1.22$ & $3-4$ & $3.6 \pm 0.55$ \\
\hline & 2 & $1-2$ & $1.6 \pm 0.55$ & $2-5$ & $3.4 \pm 1.34$ & $1-5$ & $3.4 \pm 1.82$ \\
\hline & 3 & $0-2$ & $1.0 \pm 1.0$ & $2-4$ & $2.8 \pm 0.84$ & $2-4$ & $3.0 \pm 0.71$ \\
\hline & 4 & $0-2$ & $0.6 \pm 0.89$ & $1-3$ & $2.0 \pm 1.0$ & $1-4$ & $2.4 \pm 1.14$ \\
\hline & March 1 & $0-1$ & $0.4 \pm 0.55$ & $0-2$ & $1.0 \pm 0.71$ & $0-4$ & $1.6 \pm 1.67$ \\
\hline & 2 & - & - & - & - & - & - \\
\hline
\end{tabular}

Garden-I Veterinary garden

Table 2. Number of predators occurred at vegetative and reproductive stages of red mite infesting marigold plants in Garden II (2004-2005)

\begin{tabular}{|c|c|c|c|c|c|c|c|}
\hline \multirow{4}{*}{$\begin{array}{l}\text { Plant } \\
\text { stages }\end{array}$} & \multirow{4}{*}{ Sampling week } & \multicolumn{6}{|c|}{ Adult predator (no.)/plant } \\
\hline & & \multicolumn{6}{|c|}{ Garden II } \\
\hline & & \multicolumn{2}{|c|}{ Stethorus punctillum } & \multicolumn{2}{|c|}{ Micraspis discolor } & \multicolumn{2}{|c|}{ Spiders } \\
\hline & & Range & $\bar{X} \pm \mathrm{SE}$ & Range & $\bar{X} \pm \mathrm{SE}$ & Range & $\bar{X} \pm \mathrm{SE}$ \\
\hline \multirow{11}{*}{ 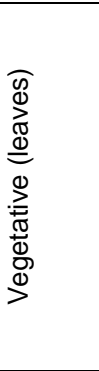 } & 2004 & & & & & & \\
\hline & November 1 & - & - & - & - & - & - \\
\hline & 2 & - & - & - & - & - & - \\
\hline & 3 & - & - & $0-1$ & $0.2 \pm 0.45$ & - & - \\
\hline & 4 & - & - & $0-1$ & $0.4 \pm 0.55$ & $0-1$ & $0.4 \pm 0.55$ \\
\hline & December 1 & $0-1$ & $0.2 \pm 0.45$ & $0-2$ & $0.6 \pm 0.89$ & $0-2$ & $0.6 \pm 0.89$ \\
\hline & 2 & $0-1$ & $0.2 \pm 0.45$ & $0-3$ & $1.2 \pm 1.30$ & $1-1$ & $1.0 \pm 0.0$ \\
\hline & 3 & $0-1$ & $0.2 \pm 0.45$ & $0-3$ & $1.4 \pm 1.14$ & $0-2$ & $1.0 \pm 0.71$ \\
\hline & 4 & $0-2$ & $0.4 \pm 0.89$ & $1-4$ & $2.2 \pm 1.1$ & $0-2$ & $1.2 \pm 0.84$ \\
\hline & 2005 & & & & & & \\
\hline & January 1 & $0-2$ & $1.0 \pm 1.0$ & $2-4$ & $2.6 \pm 0.89$ & $1-4$ & $2.0 \pm 1.41$ \\
\hline \multirow{9}{*}{ 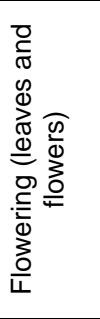 } & 2 & $1-2$ & $1.4 \pm 0.55$ & $2-4$ & $2.8 \pm 0.84$ & $1-5$ & $2.4 \pm 1.52$ \\
\hline & 3 & $1-2$ & $1.6 \pm 0.55$ & $2-6$ & $4.0 \pm 1.58$ & $2-4$ & $3.0 \pm 1.0$ \\
\hline & 4 & $1-3$ & $2.0 \pm 0.71$ & $2-7$ & $4.4 \pm 2.07$ & $2-6$ & $3.8 \pm 1.48$ \\
\hline & February 1 & $0-3$ & $1.4 \pm 1.34$ & $2-4$ & $3.4 \pm 0.89$ & $2-5$ & $3.4 \pm 1.14$ \\
\hline & 2 & $0-2$ & $1.2 \pm 0.84$ & $2-4$ & $3.2 \pm 0.84$ & $1-4$ & $3.0 \pm 1.22$ \\
\hline & 3 & $0-2$ & $0.8 \pm 0.84$ & $1-4$ & $2.4 \pm 1.14$ & $2-3$ & $2.4 \pm 0.55$ \\
\hline & 4 & $0-1$ & $0.4 \pm 0.55$ & $0-3$ & $1.8 \pm 1.30$ & $0-3$ & $1.6 \pm 1.14$ \\
\hline & March 1 & $0-1$ & $0.2 \pm 0.45$ & $0-2$ & $0.8 \pm 1.10$ & $0-3$ & $1.2 \pm 1.30$ \\
\hline & 2 & - & - & - & - & - & - \\
\hline
\end{tabular}

Garden- II Botanical garden 
Table 3. Number of predators occurred at vegetative and reproductive stages of red mite infesting marigold plants in Garden III (2004-2005)

\begin{tabular}{|c|c|c|c|c|c|c|c|}
\hline \multirow{4}{*}{$\begin{array}{c}\text { Plant } \\
\text { stages }\end{array}$} & \multirow{4}{*}{ Sampling week } & \multicolumn{6}{|c|}{ Adult predator (no.)/plant } \\
\hline & & \multicolumn{6}{|c|}{ Garden III } \\
\hline & & \multicolumn{2}{|c|}{ Stethorus punctillum } & \multicolumn{2}{|c|}{ Micraspis discolor } & \multicolumn{2}{|c|}{ Spiders } \\
\hline & & Range & $\bar{X} \pm \mathrm{SE}$ & Range & $\bar{X} \pm \mathrm{SE}$ & Range & $\bar{X} \pm \mathrm{SE}$ \\
\hline \multirow{10}{*}{ 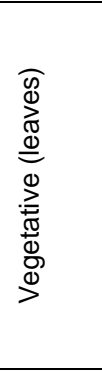 } & 2004 & & & & & & \\
\hline & November 1 & - & - & - & - & - & - \\
\hline & 2 & - & - & - & - & - & - \\
\hline & 3 & - & - & $0-1$ & $0.2 \pm 0.45$ & - & - \\
\hline & 4 & - & - & $0-1$ & $0.2 \pm 0.45$ & $0-1$ & $0.2 \pm 0.45$ \\
\hline & December 1 & - & - & $0-2$ & $0.6 \pm 0.89$ & $0-2$ & $0.6 \pm 0.89$ \\
\hline & 2 & $0-1$ & $0.2 \pm 0.45$ & $0-2$ & $0.8 \pm 1.10$ & $0-1$ & $0.6 \pm 0.55$ \\
\hline & 3 & $0-1$ & $0.2 \pm 0.45$ & $0-2$ & $1.2 \pm 0.84$ & $0-2$ & $0.8 \pm 0.84$ \\
\hline & 4 & $0-2$ & $0.4 \pm 0.89$ & $1-4$ & $2.0 \pm 1.22$ & $0-2$ & $1.0 \pm 1.0$ \\
\hline & 2005 January 1 & $0-2$ & $1.0+0.71$ & 0-4 & $2.2+1.64$ & $0-3$ & $1.4+1.14$ \\
\hline \multirow{9}{*}{ 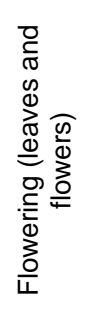 } & 2 & $0-2$ & $1.2 \pm 1.1$ & $1-6$ & $2.8 \pm 2.05$ & $1-3$ & $2.2 \pm 0.84$ \\
\hline & 3 & $1-2$ & $1.6 \pm 0.55$ & $3-5$ & $3.8 \pm 0.84$ & $2-4$ & $2.6 \pm 0.89$ \\
\hline & 4 & $1-3$ & $1.8 \pm 0.84$ & $2-8$ & $4.0 \pm 2.83$ & $2-4$ & $3.2 \pm 0.84$ \\
\hline & February 1 & $0-3$ & $1.2 \pm 1.30$ & $1-5$ & $3.2 \pm 1.64$ & $1-5$ & $3.2 \pm 1.64$ \\
\hline & 2 & $0-3$ & $1.2 \pm 1.64$ & $2-3$ & $2.6 \pm 0.55$ & 1-4 & $3.0 \pm 1.22$ \\
\hline & 3 & $0-2$ & $0.8 \pm 1.10$ & $1-3$ & $1.8 \pm 0.84$ & $1-3$ & $2.0 \pm 1.0$ \\
\hline & 4 & $0-1$ & $0.4 \pm 0.55$ & $0-2$ & $1.2 \pm 0.84$ & $0-2$ & $1.2 \pm 1.10$ \\
\hline & March 1 & - & - & $0-2$ & $0.6 \pm 0.89$ & $0-2$ & $0.6 \pm 0.89$ \\
\hline & 2 & - & - & - & - & - & - \pm \\
\hline
\end{tabular}

Garden- III Horticulture garden

Among the recorded predators all were more abundant in Garden I. The highest number of 2.4 S. punctillum, 4.6 M. discolor and 4.2 spiders per plant were present in Garden I in the last week of January (Table 1). In other two gardens their population were low (Tables 2 and 3). The incidence of S. punctillum was lower compared to other predators in all the gardens and found nil until fourth week of November. The predator $M$. discolor was recorded higher in number and also found to appear earlier in comparison with other predators. The highest numbers of $M$. discolor were counted as 4.6, 4.4 and 4.0 per plant in gardens I, II and III respectively, whereas, the S. punctillum were 2.4, 2.0 and 1.8, and the spiders were 4.2, 3.8 and 3.2. A gradual and increasing trend was observed until the last week of January. Afterwards the predator populations decreased and reached nil in the second week of March (Tables 1, 2 and 3). No immature stages of these predators and any parasitoid were found on marigold plants. The flowering stage of marigold plant showed harbouring higher number of predators than its vegetative stage.

\section{Relative abundance of mite and their predators}

The abundance of predators was directly proportional to red mite. Both these populations were low in numbers at the initial phase of their occurrence in the gardens. The gradual increasing of populations showed similar patterns and reached their peaks 10.13 predators and 1354.60 mites per plant in the last week of January (Fig.1). The abundance of predator populations was positively correlated $\left(R^{2}=0.9756\right)$ with the abundance of their mite prey (Fig. 2).

\section{DISCUSSION}

Among different species of predators, spiders and $M$. discolor were dominant with comparatively small numbers of $S$. punctillum found in association with red mite on marigold plants in infested condition. Citrus red mite, Panonychus citri had natural enemies in which the coccinellid Stethorus loi and Stethorus punctillum were the most abundant (Wen, 1988 ; Kim-Kyuchin et al. 2000) population dynamics between Stethorus predators and prey (citrus red mite) were quite well synchronized. 
The predators of the red mite did not occur uniformly on infested marigold plants. Some mite infested plants recorded no predators and a few plants had predators resulting higher standard error (SE) than mean. Thus, the distribution of the predators on the prey was clump. M. discolor and spiders were almost similar in number and double than the predator, S. punctillum in all the gardens. It was found that more aggregation of predators and mites occurred in bright light than in dark as found by Gao and Kuang, 1994 and Kroon et al. 1998 who stated that immatures and adults were significantly affected by photo-period, but had little effect on eggs. The occurrence of one predator encountered on an average of 130.58 prey per week per marigold plant during its growing season. Small population of mite at early stage perhaps could not support the survivility of predators. On the other hand, the maximum number of predators could not completely suppress the mite population at its peak population because of the high rate of its multiplication. This indicated that the natural population of predators was not adequate to suppress the mite population in the marigold ecosystem.

The predators in general were more abundant where there was good source of their preys. The predator population might be influenced by the biotic and abiotic factors as stated by Sathe and Bhosale, 2001. The availability of predator population might depend on the abundance of prey, abundance of prey plants, season, climate and ethology of the predators and preys (David, 1993).

Among the predator-prey relationship, positive correlation were noticed. These results revealed that the abundance of predators fluctuated with the abundance of mite population. Khan et al. (1993) reported that aphid predator population showed significant positive correlation with prey population.

Two species of lady bird beetle viz. S. punctillum and M. discolor and two species of spiders such as lynx spider (Oxyopes sp.), long mouth spider (Tetragatha sp.) were found in the marigold gardens. $M$. discolor and spiders were recorded higher in number than S. punctillum. The abundance of predator populations was positively correlated with the abundance of their mite prey.

\section{LITERATURE CITED}

Bhadhuri, N., Ram, S. and Patil, B. D. 1989. Evaluation of some plant extract as protectant against the pulse beetle, Callosobruchus maculatus (Fab.) infesting cowpea seeds. J. Ent. Res. 9(2), 183 -187.

David, D. 1993. Insect Pest Management. CAB International. 604 p.

Devi, D. A., Mohandas, N. and Vistakshy, A. 1986. Residues of fenthion, quinophos and malathion in paddy grains following surface treatment of gunny bags. Agril. Res. J. Kerala. 24(2), 222-224.

Fishwick, R. B. 1988. Pesticide residues in grain arising from post harvest treatments. Aspects Appl. Biol. 17(2) : 37-46.

Gao, M. Y. and Kuang, X. C. 1994. Population dynamics of citrus red mite, Panonychus citri McG. in fields and its relationship to environmental factors. J. Huazhong Agril. Univ. 13(2), 124-128.

Goodland, R., Watson, C. and Ladac, G.1985. Biocides bring poisoning and pollution to third world. The Bangladesh Observer, $16^{\text {th }}$ and $17^{\text {th }}$ January, 1985.

Gorski, R. and Eajfer, B. 2003. Control of red spider mite on indoor crops using the lady bird Stethorus punctillum. Ochron Roslin. 47(1), 10-11.

Holling, C.S. 1959. The components of predation as revealed by a study of small mammal predation of the European pine sawfly. Canad. Ent. 92, 293-320.

Islam, M. A. and Nasiruddin, M. 1978. Life history and feeding habit of Micraspis discolor (F.) (Coleoptera : Coccinellidae). Bangladesh J. Biol. Sci. 6\&7(1), 48-49.

Khan, A. B., Haq, S. B. and Talukder, F. A. 1993. Prey-predator relationships among mustard aphid and their predators. Bangladesh J. Agril. Sci. 20(1), 119-124.

Kim-Kyuchin, Choi-Ducksoo, Kim, K. C. and Choi, D. S. 2000. Natural enemies of citrus red mite, Panonychus citri McGregor and seasonal occurrence of major predators on Yuzu tree (Citrus Junos). Korean J. Appl. Entomol. 39(1), 13-19. 


\section{M.A. Taleb \& M.A. Sardar}

Kneifl, V. and Knourkova, J. 1991. Using the predatory mite, Typhlodromus pyri Scheuten in integrated apple pest management. Sbornik UVTIZ, Zahradnictvi. 18(2), 145-149.

Kroon, A., Veenendaal, R. L. and Veerman, A. 1998. Response to photoperiod during diapause development in the spider mite, Tetranychus urticae. J. Insect Physiology. 44(3-4), 271-277.

Mani, M. 1995. Studies of natural enemies of wax scale, Drepanococcus chiton (Green) on ber and guava. Entom. 20(2), 55-58.

Nucifora, A. and Vacante, V. 1985. Present possibilities of control of red spider mite in protected horticultural and floricultural crops. Tecnica Agricola. 37(3-4), 323-345.

Okuma, C., Kamal, N. Q., Hirashima, Y. Alam, M. Z. and Ogata, K. 1993. Illustrated monograph of the rice field spiders of Bangladesh. IPSA-JICA Project, Publication No. 1. Salna, Gazipur, Bangladesh. pp. 1-92.

Omkar. 2006. Suitability of different foods for a generalist ladybird beetle, Micraspis discolor (Coleoptera : Coccinellidae). Intl. J. Trop. Insect Sci. 26(1), 35-40.

Palaniswami, M. S., Pillai, K. S., Mair, R. R. and Mohandas, C. 1995. A new cassava pest in India. Cassava Newsletter, 19(1), 6-7.

Rabb, R. L. 1974. Naturally occurring biological control in the eastern United States, with particular reference to tobacco insects. In : Huffaker, C.B. (ed.). Biological control. Plenum Publ. Co. New York, 294-309.

Sathe, T. V. and Bhosale, Y. A. 2001. Insect Pest Predators. Daya Publishing House. Delhi-110035. 169 p.

Shojai, M., Ostovan, H., Hoseini Khodaman, M. and Daniali, M. 1996. The occurrence of Orius minutes (L.) in apple orchards Mashhad. Biology and Laboratory rearing for biocontrol of European red mite. J. Agril. Sci. 2(5-6), 5-20.

Sumalde, A. C., Calilung, V. J., Canlas, M. L. J. and Barile, G. 1993. Studies in the management of Thrips palmi attacking potato in the low land. Inc. College, Laguna (Philippines). $32 \mathrm{p}$.

Wen, H. C. 1988. Seasonal occurrence and chemical control of the citrus red mite, Panonychus citri (McGregor) on carambola. J. Agril. Res. China. 37(1), 100-104.

Zhang, Y. X., Zhang, Z. Q., Chen, C. P., Lin, J. Z. and Chen, X. 2001. Amblyseius cucumeris (Acari : Phytoseiidae) as a biocontrol agent against Panonychus citri (Acari : Tetranychidae) on citrus in China. Systematic and Applied Acarology. 6, 35-44. 